\title{
Follicle cell regulation of protein synthesis and developmental competence in sheep oocytes
}

\author{
I. M. Crosby, J. C. Osborn and R. M. Moor \\ A.R.C. Institute of Animal Physiology, Animal Research Station, 307 Huntingdon Road, \\ Cambridge CB3 OJQ, U.K.
}

Summary. The developmental capacity of sheep oocytes cultured outside the follicle was greatly increased by the presence of high concentrations of gonadotrophins (10 $\mu \mathrm{g} / \mathrm{ml})$ in the medium. However, even under these conditions, the developmental capacity of the oocytes was only half that of oocytes cultured within the intact follicle. The presence of the cumulus was essential for development; nearly all denuded oocytes failed to undergo cleavage.

Maturational changes in the oocyte involving increased amino acid uptake increased incorporation and specific changes in protein synthesis were inhibited by the follicle cells; this suppression was alleviated by gonadotrophic hormones. The cumulus cells suppressed amino acid incorporation and, to some extent, the changes in protein synthesis. However, the suppression of amino acid uptake required the presence of the whole follicle.

Patterns of protein synthesis by oocytes cultured outside the follicle differed from those in oocytes cultured within the follicle, irrespective of the presence of the cumulus or gonadotrophins. Analysis of single oocytes cultured outside the follicle showed that the protein profiles varied markedly even under identical culture conditions.

\section{Introduction}

The maturation of the mammalian oocyte is influenced by various external factors many of which are derived from the follicle (Masui \& Clarke, 1979). The follicle cells produce both instructional and nutritive compounds which enter the oocyte by carrier-mediated membrane transport and by pinocytosis. The closest relationship between the oocyte and follicle is provided by the cumulus cell processes which penetrate the zona pellucida and provide a route for direct intercellular communication between the somatic cells and the oocyte.

In this paper, we have investigated the ability of the cumulus cells to support the cellular changes that characterize maturation. Previous work in this laboratory has been concerned with the maturation of the oocyte within the follicle (Moor \& Trounson, 1977; Moor, Osborn, Cran $\&$ Walters, 1981) and the results of these experiments have been compared with those presented in this paper. In this way, we hope to elucidate the importance of cellular interactions between the oocyte, the cumulus and the rest of the follicle in controlling and supporting maturation.

We have chosen developmental capacity as a measure of maturation because nuclear change is not an adequate criterion of the viability of an oocyte (Chang, 1955; Moor \& Trounson, 1977). Indeed, it has been well established that nuclear maturation is little affected by the presence or absence of the cumulus cells (Cross, 1973; Binor \& Wolf, 1979; Magnusson, 1980). As a consequence, we do not consider this aspect of maturation but instead concentrate on the interactions that exist between follicle cells and gonadotrophins on the one hand, and the rates of amino acid uptake, incorporation and patterns of protein synthesis in oocytes on the other. 


\section{Materials and Methods}

\section{Tissue preparation and culture}

Ovaries were obtained (i) from Welsh Mountain ewes injected with 1250 i.u. PMSG on Day 10-12 of the oestrous cycle and slaughtered $40 \mathrm{~h}$ later, or (ii) from untreated sheep killed at the local abattoir. Non-atretic follicles $(3-5 \mathrm{~mm}$ in diameter) were dissected from the ovaries at room temperature and opened to remove the complete oocyte-cumulus complex. Two types of culture were carried out: (i) the complete oocyte-cumulus mass was cultured (cumulus-enclosed oocytes) or (ii) the oocyte was cultured after removal of the cumulus cells with fine pipettes (denuded oocytes). Culture was in Medium 199, supplemented with crystalline bovine serum albumin $(4 \mathrm{mg} / \mathrm{ml})$, sodium pyruvate $(0.4 \mathrm{~mm})$, kanamycin $(75 \mu \mathrm{g} / \mathrm{ml})$, insulin $(35 \mu \mathrm{g} / \mathrm{ml})$ and ascorbic acid $(70 \mu \mathrm{g} / \mathrm{ml})$, in $5 \% \mathrm{CO}_{2}$ in air at atmospheric pressure. Hormonal supplements varied and are described in the 'Results'.

After culture, cumulus-enclosed oocytes and denuded oocytes were used for one of three experiments to determine: (i) developmental capacity, (ii) amino acid uptake or (iii) patterns of protein synthesis.

The period of culture varied from 18 to $22 \mathrm{~h}$. After $18 \mathrm{~h}$ in culture there is little further change in developmental capacity (R. M. Moor, C. Polge, A. O. Trounson \& S. M. Willadsen, unpublished) or patterns of protein synthesis (J. C. Osborn, I. M. Crosby \& R. M. Moor, unpublished). For the experiment to measure developmental capacity the oocytes were cultured for $20-22 \mathrm{~h}$. This corresponds closely to the $18 \mathrm{~h}$ culture followed by $3 \mathrm{~h}$ labelling of the oocytes used in the experiment to measure protein synthetic patterns.

\section{Evaluation of developmental capacity of cultured oocytes}

After 20-22 $\mathrm{h}$ in culture, cumulus-enclosed or denuded oocytes were transferred to the oviducts of ewes in oestrus. Fresh ram semen was injected into both uterine horns immediately after transfer of the oocytes. The recipients were slaughtered 10-12 days later and the eggs and embryos were recovered from the tracts and classified according to their stage of development. Appropriate deductions from the number of blastocysts were made to allow for the recipients' own ovulations.

\section{Amino acid uptake by cultured oocytes}

Amino acid uptake by the oocytes after culture for $18 \mathrm{~h}$ was measured as described by Moor \& Smith (1979). These experiments were carried out on material from untreated ewes because uptake is increased by PMSG treatment before slaughter (Moor \& Smith, 1979).

\section{Electrophoretic analysis of oocyte proteins}

Protein profiles were examined in oocytes cultured for $18 \mathrm{~h}$. Groups of 6-10 denuded or cumulus-enclosed oocytes were incubated for $3 \mathrm{~h}$ in $50 \mu \mathrm{l}$ incubation medium containing $1 \mathrm{mCi}$ $\left.{ }^{[35} \mathrm{S}\right]$ methionine $/ \mathrm{ml}$ (sp. act. $1000 \mathrm{Ci} / \mathrm{mmol}$; Radiochemical Centre, Amersham, U.K.). After incubation, the cumulus-enclosed oocytes were denuded and all of the oocytes were washed and collected, singly or in groups, in $5 \mu \mathrm{l}$ Tris buffer and frozen, until required for electrophoresis.

Labelled oocytes were analysed by electrophoresis on 8-15\% linear gradient, SDSpolyacrylamide slab gels as described by Moor et al. (1981). Incorporation of $\left.{ }^{35} \mathrm{~S}\right]$ methionine was determined by trichloroacetic acid precipitation (Van Blerkom, 1978) and equal counts were applied to each track in any one gel. After electrophoresis at $20 \mathrm{~mA}$ per gel for $3 \mathrm{~h}$, the gels were fixed, impregnated with PPO, dried and exposed to pre-flashed Kodak X-Omat-H film at $-70^{\circ} \mathrm{C}$ (Bonner \& Laskey, 1974; Laskey \& Mills, 1975). The films were scanned on a 'Quick Scan' microdensitometer. 
Quantitative analysis of the fluorograms was carried out as described by Moor et al. (1981), using as markers 16 prominent bands which showed changes during normal maturation within the follicle. The relative amount of protein in each marker band was calculated as a percentage of the total amount of protein in the fluorogram. The results of four different treatments were compared with each other and with the results of the intrafollicular standards by canonical variate analysis (Rao, 1952).

\section{Results}

\section{The developmental capacity of oocytes cultured outside the follicle}

The effects of gonadotrophins on the development of oocytes cultured for $24 \mathrm{~h}$ outside the follicle, both in the presence and absence of cumulus cells, were determined. The results shown in Table 1 demonstrate that in the absence of gonadotrophins only $4 \%$ of cumulus-enclosed oocytes removed from the follicle developed into normal blastocysts. Since Moor \& Trounson (1977) have shown that the addition of low concentrations of FSH $(2 \mu \mathrm{g} / \mathrm{ml})$ and $\mathrm{LH}(1 \mu \mathrm{g} / \mathrm{ml})$ does not increase the percentage of oocytes developing into blastocysts, it was decided to use the relatively high concentration $(10 \mu \mathrm{g} / \mathrm{ml})$ of $\mathrm{LH}$ previously used by Shalgi, Dekel \& Kraicer (1979). This increased the proportion of blastocysts from 4 to $30 \%$. However, because oocytes cultured within the follicle with lower concentrations of hormones produced blastocysts in $56 \%$ of cases, it is evident that the cumulus cells, even when treated with high levels of gonadotrophin, are inferior to the whole follicle in their capacity to support maturation. Nevertheless, the presence of the cumulus cells is essential for development; culturing denuded oocytes with high LH resulted in only a low level of cleavage, whereas leaving the cumulus cells intact for the first $8 \mathrm{~h}$ increased the percentage undergoing cleavage to $31 \%$ although only one oocyte reached the blastocyst stage. The association of cells with the oocyte is therefore necessary for a considerable period after the induction of maturation.

Table 1. Development of sheep oocytes cultured for $24 \mathrm{~h}$ outside the follicle and transferred to the oviducts of ewes for 10-12 days

\begin{tabular}{|c|c|c|c|c|c|c|c|c|c|}
\hline Treatment & $\begin{array}{l}\text { Trans- } \\
\text { ferred }\end{array}$ & $\begin{array}{c}\mathrm{Re}- \\
\text { covered }\end{array}$ & $\begin{array}{c}\text { Single } \\
\text { cell }\end{array}$ & $\begin{array}{l}\text { Frag- } \\
\text { mented }\end{array}$ & $\begin{array}{c}\text { Retarded } \\
(2-50 \\
\text { cells })\end{array}$ & $\begin{array}{c}\text { Small } \\
\text { abnormal } \\
\text { blastocyst }\end{array}$ & $\begin{array}{l}\text { Normal } \\
\text { blasto- } \\
\text { cysts }\end{array}$ & $\begin{array}{c}\text { Deductions } \\
\text { for } \\
\text { recipient's } \\
\text { ovulations }\end{array}$ & $\begin{array}{c}\text { Normal } \\
\text { blastocysts } \\
(\%)\end{array}$ \\
\hline $\begin{array}{l}\text { Control, } \\
\text { cumulus } \\
\text { enclosed }\end{array}$ & 56 & 45 & 29 & 10 & 2 & 1 & 3 & -1 & 4.4 \\
\hline $\begin{array}{l}\mathrm{LH} 10 \mu \mathrm{g} / \mathrm{ml} \text {, } \\
\text { cumulus } \\
\text { enclosed }\end{array}$ & 110 & 100 & 56 & 4 & 4 & 0 & 36 & -6 & 30 \\
\hline $\begin{array}{c}\mathrm{LH} 10 \mu \mathrm{g} / \mathrm{ml}, \\
\text { denuded }\end{array}$ & 42 & 34 & 33 & 0 & 1 & 0 & 0 & 0 & 0 \\
\hline $\begin{array}{l}\mathrm{LH} 10 \mu \mathrm{g} / \mathrm{ml}, 8 \mathrm{~h} \\
\text { cumulus- } \\
\text { enclosed } \\
16 \mathrm{~h} \text { denuded }\end{array}$ & 48 & 37 & 23 & 0 & 12 & 0 & 2 & -1 & $2 \cdot 7$ \\
\hline $\begin{array}{l}\text { Intrafollicular } \\
\text { culture } \\
\text { LH } 1 \mu \mathrm{g} / \mathrm{ml} \\
\text { FSH } 2 \mu \mathrm{g} / \mathrm{ml} \\
\text { Oestradiol } \\
1 \mu \mathrm{g} / \mathrm{ml}\end{array}$ & 77 & & & & & & 43 & & $56 \%$ \\
\hline
\end{tabular}




\section{Uptake and incorporation of amino acids}

Amino acid studies, previously published in abstract form only (Moor \& Smith, 1978), have shown that gonadotrophins significantly increase cycloleucine uptake into oocytes cultured in intact follicles; high rates of uptake were also recorded in oocytes that had been cultured outside the follicle, even in the absence of gonadotrophins. These results suggested that the intact follicle exerts an inhibitory effect on amino acid uptake. The details of these earlier experiments, presented in Table 2, are of particular relevance to the present study since they illustrate clearly the opposing actions of follicle cells and gonadotrophins on amino acid fluxes in oocytes. The results of Moor \& Smith (1978) provide the necessary foundation on which the earlier conclusions were based and suggest that one role of gonadotrophins in the initiation of maturation is to overcome the inhibitory influence of the follicle on membrane transport.

Table 2. The effect of follicle cells and gonadotrophins on amino acid uptake by sheep oocytes after culture for $18 \mathrm{~h}$ (data from Moor \& Smith, 1978)

\begin{tabular}{llcc}
\hline \multicolumn{2}{c}{ Culture conditions } & $\begin{array}{c}\text { No. of } \\
\text { oocytes }\end{array}$ & $\begin{array}{c}{\left[{ }^{14} \mathrm{C} \text { C Cycloleucine uptake }\right.} \\
\left(\mathrm{pmol} .00 \mathrm{cyt} \mathrm{e}^{-1} \cdot \mathrm{h}^{-1}\right)\end{array}$ \\
\hline Intrafollicular & Control & 62 & $3 \cdot 15 \pm 0.19 \dagger$ \\
& Hormones* & 62 & $4.95 \pm 0.29 \dagger$ \\
Extrafollicular & Control & 28 & $5 \cdot 10 \pm 0.26$ \\
& Hormones* & 35 & $4.21 \pm 0.31$ \\
\hline
\end{tabular}

Values are mean \pm s.e.m.

* Hormone additions to the culture medium consisted of $\mathrm{LH}(4 \mu \mathrm{g} / \mathrm{ml})+$ FSH $(4 \mu \mathrm{g} / \mathrm{ml})+$ oestradiol $(1 \mu \mathrm{g} / \mathrm{ml})+$ prolactin $(10 \mathrm{ng} / \mathrm{ml})$ or $\mathrm{hCG}$ (5 i.u/ml); there were no significant differences between the two media and the results are combined.

$+t$ test: $t=5.1,122$ d.f., $P<0.001$.

Table 3 shows the effect of cumulus cells and gonadotrophins on the incorporation of $\left[{ }^{35} \mathrm{~S}\right]$ methionine into oocyte proteins. When the oocytes were cultured with the cumulus present the methionine incorporation was significantly increased by the addition of hormone to the medium. However, the culture of denuded oocytes gave very variable results and too few experiments were carried out to detect any significant differences. The rates of incorporation by oocytes after culture with the cumulus present were very similar to those of oocytes cultured within the follicle (Moor et al., 1981).

Table 3. Incorporation of $\left[{ }^{35} \mathrm{~S}\right]$ methionine into oocytes after extrafollicular culture for $18 \mathrm{~h}$

\begin{tabular}{llcc}
\hline \multicolumn{1}{c}{ Culture conditions } & $\begin{array}{c}\text { No. of groups } \\
\text { of oocytes }\end{array}$ & $\begin{array}{c}\text { Mean } \pm \text { s.e.m. incorporation } \\
\left(\mathrm{fmol.oocytt^{-1 }} \cdot \mathrm{h}^{-1}\right)\end{array}$ \\
\hline Cumulus-enclosed & Control & 10 & $6.04 \pm 0.58 \dagger$ \\
\multirow{4}{*}{ Denuded } & High LH $(10 \mu \mathrm{g} / \mathrm{ml})$ & 10 & $8.57 \pm 0.83 \dagger$ \\
& Control & 5 & $8.13 \pm 1.77$ \\
& High LH $(10 \mu \mathrm{g} / \mathrm{ml})$ & 7 & $6.58 \pm 1.34$ \\
\hline
\end{tabular}

* Each group contained 4-10 oocytes.

$\dagger$ Paired $t$ test: $t=3.59,9$ d.f., $P<0.01$.

Patterns of protein synthesis

It is well established that changes in the pattern of protein synthesis occur during oocyte maturation (Golbus \& Stein, 1976; Schultz \& Wassarman, 1977a, b; Warnes, Moor \& Johnson, 1977; Van Blerkom \& McGaughey, 1978a). However, there is little information available at 
present on the mechanisms that initiate these changes. We have therefore applied a quantitative analysis to the patterns of protein synthesis in extrafollicular oocytes in an attempt to elucidate the interactions of the follicle cells and gonadotrophins in controlling the changes in protein synthesis. The patterns of protein synthesis were examined in cumulus-enclosed and denuded extrafollicular oocytes cultured for $18 \mathrm{~h}$ in the presence and absence of high $\mathrm{LH}(10 \mu \mathrm{g} / \mathrm{ml})$. The patterns produced by intrafollicular culture with and without gonadotrophins (Moor et al., 1981) were used as the standard indicative of normal pre- and post-maturational patterns respectively.

Text-figure 1 shows the results of canonical variate analysis of the four extrafollicular treatments and the two intrafollicular standards. The generalized distance table (Table 4) gives a measure of the degree of difference between the centroids of the treatment groups. This distance takes into account all 16 canonical variates, whereas the diagram shows only the first two variates which account for $84.5 \%$ of the total variability. The most noticeable feature of this diagram is that all four extrafollicular groups are clearly separated from the two intrafollicular standards. When compared with the intrafollicular standards, it is clear that the untreated cumulus-enclosed oocytes show intermediate patterns of protein synthesis which range from the intrafollicular control group towards the hormone-treated groups. By contrast, the culture of cumulus-enclosed oocytes with high LH produced patterns of synthesis closer to those of the hormone-treated, intrafollicular oocytes than any other group, although the two groups were still distinct from each other. Similarly, the patterns of protein synthesis in the denuded oocytes were very different from the untreated intrafollicular controls, but were close to, yet distinct from, the treated intrafollicular group.

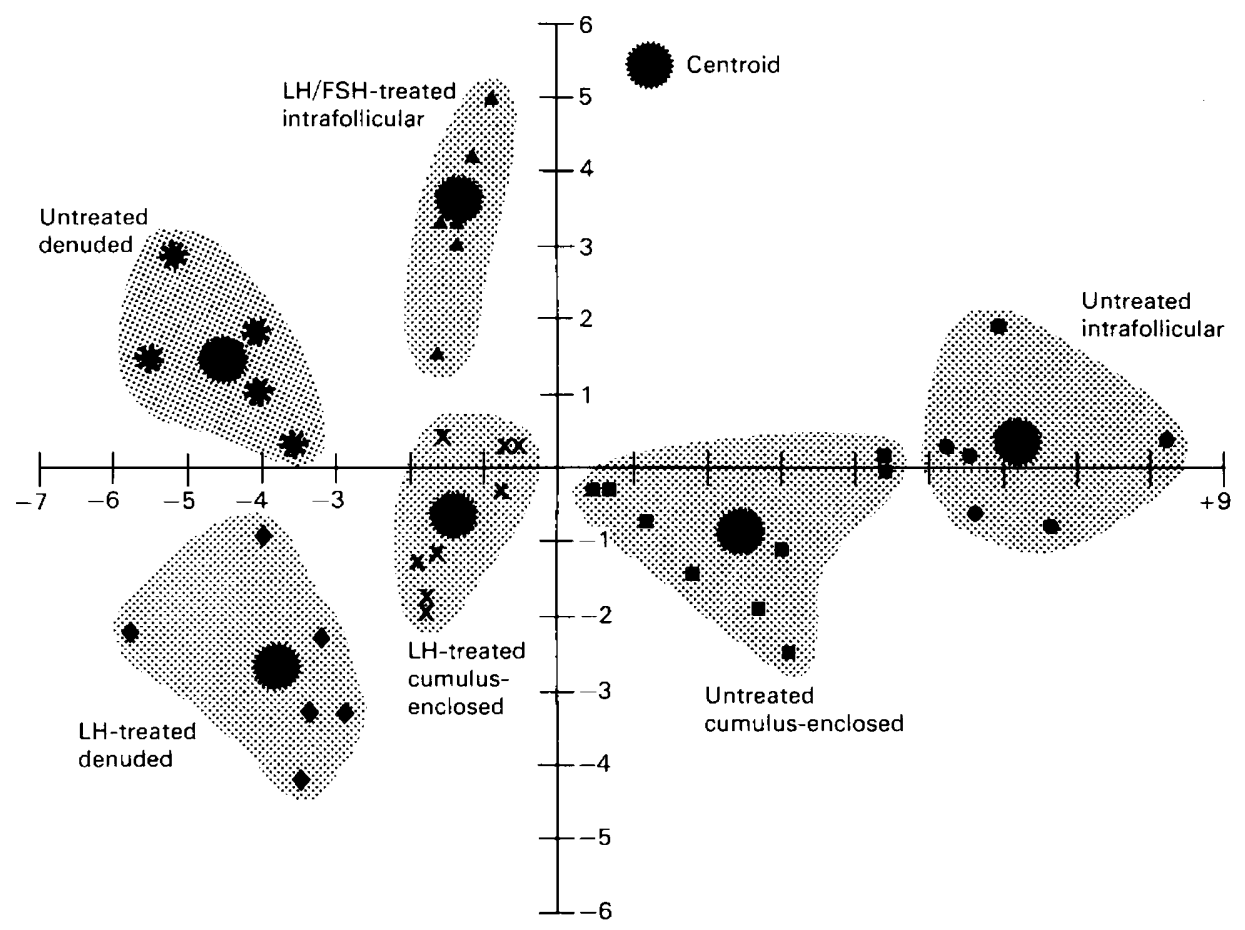

Text-fig. 1. Canonical variate analysis of the patterns of protein synthesis in oocytes cultured with different degrees of follicle cell and gonadotrophin support. The first two canonical variates, showing $84.5 \%$ of the separation, are plotted. 
Table 4. Generalized distances between centroids of treatment groups (see Text)

\begin{tabular}{lccccc}
\hline & $\begin{array}{c}\text { Intrafollicular } \\
\text { untreated }\end{array}$ & $\begin{array}{c}\text { Intrafollicular } \\
\text { LH/FSH }\end{array}$ & $\begin{array}{c}\text { Cumulus-enclosed } \\
\text { untreated }\end{array}$ & $\begin{array}{c}\text { Cumulus-enclosed } \\
\text { LH } 10 \mu \mathrm{g} / \mathrm{ml}\end{array}$ & $\begin{array}{c}\text { Denuded } \\
\text { untreated }\end{array}$ \\
\hline $\begin{array}{l}\text { Intrafollicular untreated } \\
\text { Intrafollicular LH/FSH }\end{array}$ & - & 8.4 & - & & \\
$\begin{array}{l}\text { Cumulus-enclosed } \\
\quad \text { untreated }\end{array}$ & 4.9 & 6.0 & - & & \\
$\begin{array}{l}\text { Cumulus-enclosed } \\
\text { LH 10 } \mu \mathrm{g} / \mathrm{ml}\end{array}$ & 10.9 & 4.7 & 7.7 & - & \\
$\begin{array}{l}\text { Denuded untreated } \\
\text { Denuded LH } 10 \mu \mathrm{g} / \mathrm{ml}\end{array}$ & 8.3 & 4.6 & 4.6 & 5.6 & -6.9 \\
\hline
\end{tabular}

Since each of the experiments described above was carried out using groups of 4-10 oocytes, it seemed probable that the variability of the results for any one treatment could be partly due to variation between individual oocytes within the groups. To test this hypothesis, the patterns of protein synthesis were compared in individual, cumulus-enclosed oocytes, cultured and treated in the same way as the groups. Since the fluorograms from these experiments resembled one or other of the intrafollicular patterns, they were assessed visually. Without hormone treatment, approximately $30 \%$ of the oocytes showed a 'post-maturational' pattern, whereas the addition of gonadotrophin produced changes in $70 \%$ of the oocytes. A statistical analysis was also carried out on one of the gels (Plate 1) to judge the results of the visual assessment. The 13 tracks on the gel were divided by eye into two groups for the canonical variate analysis; 8 were judged to show post-maturational and 5 to show prematurational patterns. The analysis confirmed that the groups were indeed distinct; the separation between them, as measured by the generalized distance, was 8.8 , compared with 5.4 between the treated and untreated oocyte groups included in the analysis. These results show that much of the variation between different groups of oocytes given the same treatment is due to variation between individual oocytes.

\section{Discussion}

In these studies we have investigated intercellular relationships within the follicle to determine the relative importance of its different cellular components in the control and support of oocyte maturation. Initial experiments were carried out to compare the developmental capacity of oocytes removed from the follicle and cultured, with or without the cumulus cells, with that of oocytes cultured within the follicle. Previous work (Moor \& Trounson, 1977) has shown that oocytes cultured outside the follicle, even in the presence of hormones $(2 \mu \mathrm{g} \mathrm{FSH} / \mathrm{ml} ; 1 \mu \mathrm{g}$ $\mathrm{LH} / \mathrm{ml} ; 1 \mu \mathrm{g}$ oestradiol $/ \mathrm{ml}$ ), do not undergo normal development when transferred to recipients; e.g. although $70-80 \%$ of oocytes matured in vitro resumed meiosis, only $1 \%$ developed into blastocysts. Similarly, Cross \& Brinster (1970) and Van Blerkom \& McGaughey (1978b) have achieved only limited succcess with mouse and rabbit oocytes respectively. However, Shalgi $e t$ al. (1979) improved the developmental capacity of rat oocytes cultured outside the follicle by adding a high concentration of $\mathrm{LH}\left(10 \mu \mathrm{g} . \mathrm{ml}^{-1}\right)$ to the culture medium. This increased the proportion showing normal fertilization from 11 to $33 \%$ and almost $10 \%$ of the oocytes produced normal young, compared with 61 and $30 \%$ respectively for oocytes matured in vivo.

Our results confirm that the presence of a high concentration of LH greatly increases the proportion of eggs developing into blastocysts. However, at this concentration the contamination of the hormone with FSH is significant (up to 5\%), and the treatment can be regarded as a combined gonadotrophin treatment. Nevertheless, even under these conditions, the developmental capacity of extrafollicular oocytes is approximately half that of oocytes from 


\section{PLATE 1}

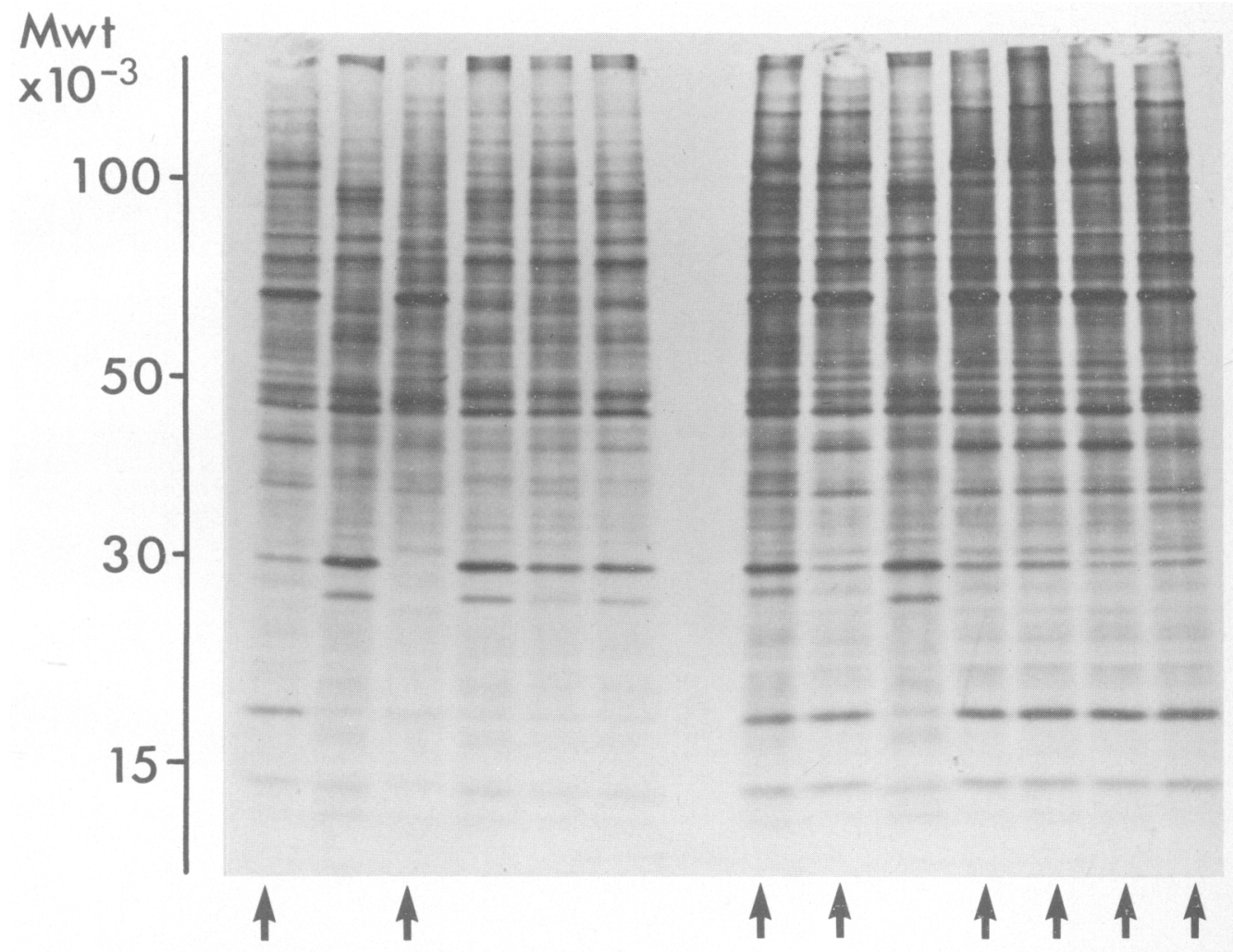

Fluorogram of polacrylamide gel containing 13 samples of cumulus-enclosed, gonadotrophin-treated oocytes. The arrows mark the 8 tracks judged to show post-maturational patterns of protein synthesis.

(Facing p. 580) 
cultured intact follicles. Furthermore, the results clearly show that the continuous presence of the cumulus cells during maturation is essential for early development.

Although we have not studied nuclear maturation in this investigation, it is well established that, in the absence of gonadotrophins, the follicle inhibits nuclear change, but that the cumulus cells alone are unable to do so (Masui \& Clarke, 1979). The follicle cells are thought to produce a small protein which inhibits meiosis (Chang, 1955; Foote \& Thibault, 1969; Tsafriri, Pomerantz \& Channing, 1976). Since the presence of the cumulus is necessary for the inhibitory action of the follicle, it is likely that the action of the follicle cells is mediated through the cumulus (Hillensjo, Kripner, Pomerantz \& Channing, 1979). The same basic mechanism of gonadotrophin-relieved follicular inhibition is revealed by our studies of other maturational events.

The rate of amino acid uptake across the oocyte membrane increases significantly during maturation (Moor \& Smith, 1978, 1979), and can be induced by removing the follicle cells but leaving the cumulus cells intact, or by gonadotrophin administration. This implies an inhibitory effect of the follicle on membrane transport which is overcome by hormones. Similarly, the incorporation of amino acids into proteins is also increased by gonadotrophins. However, in this case the cumulus cells alone are capable of inhibiting incorporation, whereas denuded oocytes show very variable rates. Hormone-treated, cumulus-clad oocytes incorporate labelled amino acids at a rate indistinguishable from that of similarly treated intrafollicular oocytes (Moor et al., 1981). This illustrates the differences that occur in the relative importance of the cumulus cells and other cellular components of the follicle in controlling maturational changes.

The results of the canonical variate analyses of protein synthetic patterns also suggest that the cumulus cells exert an inhibitory effect upon maturation which can be alleviated by gonadotrophins. However, the following observations indicate that the other follicle cells also have a role in controlling protein synthesis. Firstly, some cumulus-enclosed oocytes undergo changes in protein synthesis without hormone treatment, indicating that the cumulus cells alone are not always capable of inhibiting protein synthetic changes. Secondly, the changes in LH-treated, cumulus-enclosed oocytes are similar but not identical to those occurring in oocytes cultured within the follicle.

It is not clear how LH influences the patterns of protein synthesis in denuded oocytes; it does not seem to bring the patterns of synthesis closer to those found in intrafollicular treated oocytes. One major difference between the patterns of protein synthesis in the denuded oocytes and those in the other treatment groups is a large decrease in the amount of incorporation into one band in particular. We believe that the major component of this band is actin and suggest that the presence of newly synthesized actin in the oocyte is dependent upon a form of cellular co-operation between the cumulus cells and oocytes, which may involve pinocytosis (J.C. Osborn \& R. M. Moor, unpublished observations). Other presynthesized proteins such as albumin and globulins are known to enter the oocyte (Glass, 1971) while Moor, Smith \& Dawson (1980) have shown that a number of metabolic products, including choline, uridine and inositol, can only enter the oocyte via the cumulus cells, probably by direct intercellular transfer through junctional complexes. In addition, the cumulus cells also provide an energy source for the oocyte in the form of pyruvate, the oocyte itself being unable to metabolize glucose (Biggers, Whittingham \& Donahue, 1967). The importance of the nutritional contribution of the cumulus to the oocyte is demonstrated in our studies by the inability of denuded oocytes to undergo fertilization and development.

The maturation of the mammalian oocyte is regarded by some workers as an overcoming of the inhibitory effect of the follicle by gonadotrophins, but this is clearly an oversimplification. The follicle, and in particular the cumulus cells, has a major supportive or nutritive role during maturation. Furthermore, our studies have shown that the various suppressive actions of the follicle, on the nucleus, amino acid transport and incorporation, and protein synthesis, differ in the relative contributions of the cumulus and the other follicle cells, which may reflect differences in the mechanisms of suppression and sites of hormone action. 
We thank Dr D. E. Walters of the A.R.C. Statistics Group, Department of Applied Biology, Cambridge, for his advice on the statistical analysis. The purified gonadotrophin was generously donated by the NIAMDD, National Institute of Health, Bethesda, Maryland. One of us (J.C.O.) is indebted to the Medical Research Council for financial support.

\section{References}

Biggers, J.D., Whittingham, D.G. \& Donahue, R.P. (1967) The pattern of energy metabolism in the mouse oocyte and zygote. Proc. natn. Acad. Sci. U.S.A. 58, 560-567.

Binor, Z. \& Wolf, D.P. (1979) In-vitro maturation and penetration of primary mouse oocytes after removal of the zona pellucida. J. Reprod. Fert. 56, 309-314.

Bonner, W.M. \& Laskey, R.A. (1974) Film detection method for tritium-labelled proteins and nucleic acids in poly acrylamide gels. Eur.J. Biochem. 46, 83-88.

Chang, M.C. (1955) The maturation of rabbit oocytes in culture and their maturation, activation, fertilization and subsequent development in the Fallopian tubes. J. exp. Zool. 128, 379-405.

Cross, P.C. (1973) The role of cumulus cells and serum in mouse oocyte maturation in vitro. J. Reprod. Fert. 34, 241-245.

Cross, P.C. \& Brinster, R.L. (1970) In vitro development of mouse oocytes. Biol. Reprod. 3, 298-307.

Foote, W.D. \& Thibault, C. (1969) Recherches experimentales sur la maturation in vitro des ovocytes de truie et de veau. Annls Biol. anim. Biochim. Biophys. 9, 329-349.

Glass, L.E. (1971) Transmission of maternal proteins into oocytes. Adv. Biosci. 6, 29-61.

Golbus, M.S. \& Stein, M.P. (1976) Qualitative patterns of protein synthesis in the mouse oocyte. $J$. exp. Zool. 198, 337-342.

Hillensjo, T., Kripner, A.S., Pomerantz, S.H. \& Channing, C.P. (1979) Action of porcine follicular fluid oocyte maturation inhibition in vitro: possible role of the cumulus cells. In Ovarian, Follicular and Corpus Luteum Function, pp. 283-290. Eds C.P. Channing, J. M. Marsh \& W. A. Sadler. Plenum Press, New York.

Laskey, R.A. \& Mills, A.D. (1975) Quantitative film detection of ${ }^{3} \mathrm{H}$ and ${ }^{14} \mathrm{C}$ in polyacrylamide gels by fluorography. Eur. J. Biochem. 56, 335-341.

Magnusson, C. (1980) Role of cumulus cells for rat oocyte maturation and metabolism. Gamete Res. 3, $133-140$.

Masui, Y. \& Clarke, H.J. (1979) Oocyte maturation. Int. Rev. Cytol. 57, 185-282.

Moor, R.M. \& Smith, M.W. (1978) Amino acid uptake in to sheep oocytes. J. Physiol., Lond. 284, 68-69P.

Moor, R.M. \& Smith, M.W. (1979) Amino acid transport in mammalian oocytes. Expl Cell Res. 119, $333-341$
Moor, R.M. \& Trounson, A.O. (1977) Hormonal and follicular factors affecting maturation of sheep oocytes in vitro and their subsequent developmental capacity. J. Reprod. Fert. 49, 101-109.

Moor, R.M., Smith, M.W. \& Dawson, R.M.C. (1980) Measurement of intercellular coupling between oocytes and cumulus cells using intracellular markers. Expl Cell Res. 126, 15-29.

Moor, R.M., Osborn, J.C., Cran, D.G. \& Walters, D.E. (1981) Selective effects of gonadotrophins on cell coupling, nuclear maturation and protein synthesis in mammalian oocytes. J. Embryol. Exp. Morph. 61, $347-365$

Rao, C.R. (1952) Advanced Statistical Methods in Biometric Research. Wiley, New York.

Schultz, R.M. \& Wassarman, P.M. (1977a) Specific changes in the pattern of protein synthesis during meiotic maturation of mammalian oocytes in vitro. Proc. natn. Acad. Sci. U.S.A. 74, 538-541.

Schultz, R.M. \& Wassarman, P.M. (1977b) Biochemical studies of mammalian oogenesis: protein synthesis during oocyte growth and meiotic maturation in the mouse. J. Cell Sci. 24, 167-194.

Shalgi, R., Dekel, N. \& Kraicer, P.F. (1979) The effect of LH on the fertilizability and developmental capacity of rat oocytes matured in vitro. J. Reprod. Fert. 55, 429-435.

Tsafriri, A., Pomerantz, S.H. \& Channing, C.P. (1976) Inhibition of oocyte maturation by porcine follicular fluid: partial characterization of the inhibitor. Biol. Reprod. 14, 511-516.

Van Blerkom, J. (1978) Methods for the high resolution analysis of protein synthesis: applications to studies of early mammalian development. In Methods in Mammalian Reproduction, pp. 67-109. Ed. J. C. Daniel. Academic Press, London.

Van Blerkom, J. \& McGaughey, R.W. (1978a) Molecular differentiation of the rabbit ovum. I. During oocyte maturation in vivo and in vitro. Devl Biol. 63, $139-150$.

Van Blerkom, J. \& McGaughey, R.W. (1978b) Molecular differentiation of the rabbit ovum. II. During the preimplantation development of in vivo and in vitro matured oocytes. Devl Biol. 63, 151-164.

Warnes, G.M., Moor, R.M. \& Johnson, M.H. (1977) Changes in protein synthesis during maturation of sheep oocytes in vivo and in vitro. J. Reprod. Fert. 49, 331-335. 